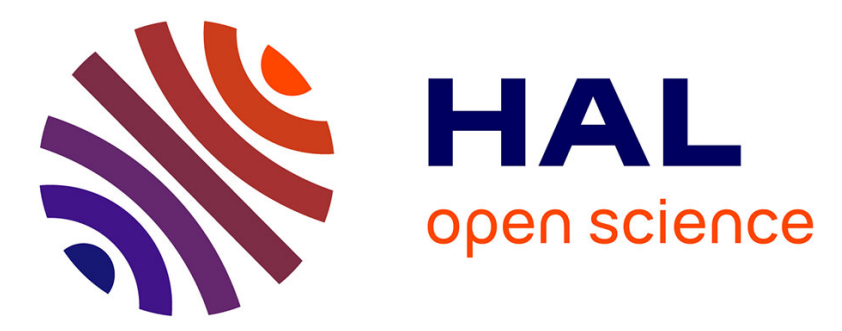

\title{
Inorganic-organic hybrid double sulfates as catalysts of the diastereoselective nitroaldol reaction
}

\author{
Omar Kammoun, Walid Rekik, Thierry Bataille, Kamran T. Mahmudov, \\ Maximilian N. Kopylovich, Houcine Naïli
}

\section{- To cite this version:}

Omar Kammoun, Walid Rekik, Thierry Bataille, Kamran T. Mahmudov, Maximilian N. Kopylovich, et al.. Inorganic-organic hybrid double sulfates as catalysts of the diastereoselective nitroaldol reaction. Journal of Organometallic Chemistry, 2013, 741-742, pp.136-140. 10.1016/j.jorganchem.2013.05.028 . hal-00860183

HAL Id: hal-00860183

https://hal-univ-rennes1.archives-ouvertes.fr/hal-00860183

Submitted on 10 Sep 2013

HAL is a multi-disciplinary open access archive for the deposit and dissemination of scientific research documents, whether they are published or not. The documents may come from teaching and research institutions in France or abroad, or from public or private research centers.
L'archive ouverte pluridisciplinaire HAL, est destinée au dépôt et à la diffusion de documents scientifiques de niveau recherche, publiés ou non, émanant des établissements d'enseignement et de recherche français ou étrangers, des laboratoires publics ou privés. 


\section{Journal of Organometallic Chemistry}

\section{Inorganic-organic hybrid double sulfates as catalysts of the diastereoselective nitroaldol reaction}

Omar Kammoun ${ }^{\mathrm{a}, \mathrm{b}}$, Walid Rekik ${ }^{\mathrm{a}}$, Tahar Mhiri ${ }^{\mathrm{a}}$, Thierry Bataille ${ }^{\mathrm{b}}$, Kamran T. Mahmudov, ${ }^{\mathrm{c}, \mathrm{d}}$ Maximilian N. Kopylovich, ${ }^{\mathrm{c}, *}$ and Houcine Naïli ${ }^{\mathrm{a}, *}$

${ }^{a}$ Laboratoire physico-chimie de l'État Solide, Faculté des Sciences de Sfax, Université de Sfax, BP 1171, 3000 Sfax, Tunisie.

${ }^{b}$ Institut des Sciences Chimiques de Rennes UMR CNRS 6226, Université de Rennes 1 UEB, Avenue du Général Leclerc, F-35042 Rennes Cedex, France

${ }^{c}$ Centro de Química Estrutural, Complexo I, Instituto Superior Técnico, Technical University of Lisbon, Av. Rovisco Pais, 1049-001 Lisbon, Portugal

${ }^{d}$ Baku State University, Department of Chemistry, Z. Xalilov Str. 23, Az 1148 Baku, Azerbaijan

${ }^{*}$ Corresponding authors:

E-mail addresses: kopylovich@yahoo.com (Maximilian N. Kopylovich) and houcine_naili@yahoo.com (Houcine Naïli)

Tel: +216 986600 26; fax: +21674 274437 


\section{Graphical Abstract}

New inorganic-organic hybrid materials effectively and diastereoselectively catalyze the $\mathrm{C}-\mathrm{C}$ bond formation upon nitroaldol (Henry) reaction.

\section{Highlights}

New hybrid materials were easily prepared from zinc(II) salt, sulfuric acid and amines.

Full structural characterization of the compounds was performed.

The synthesized compounds act as effective catalysts in the nitroaldol (Henry) reaction. 


\begin{abstract}
Bis(1-phenylethanaminium)

disulfatotetraaquazincate(II)

dihydrate

$\left(\mathrm{C}_{8} \mathrm{H}_{12} \mathrm{~N}\right)_{2}\left[\mathrm{Zn}\left(\mathrm{H}_{2} \mathrm{O}\right)_{4}\left(\mathrm{SO}_{4}\right)_{2}\right] \cdot 2 \mathrm{H}_{2} \mathrm{O}(\mathbf{1})$, bis(1H-benzo[d]imidazolium) hexaaquazinc(II) bis(sulfate)

tetrahydrate $\quad\left(\mathrm{C}_{7} \mathrm{H}_{7} \mathrm{~N}_{2}\right)_{2}\left[\mathrm{Zn}\left(\mathrm{H}_{2} \mathrm{O}\right)_{6}\right]\left(\mathrm{SO}_{4}\right)_{2} \cdot 4 \mathrm{H}_{2} \mathrm{O} \quad$ (2) and bis(2-methyl-1H-imidazolium) hexaaquazinc(II) bis(sulfate) dihydrate $\left(\mathrm{C}_{4} \mathrm{H}_{7} \mathrm{~N}_{2}\right)_{2}\left[\mathrm{Zn}\left(\mathrm{H}_{2} \mathrm{O}\right)_{6}\right]\left(\mathrm{SO}_{4}\right)_{2} \cdot 2 \mathrm{H}_{2} \mathrm{O} \quad$ (3) have been synthesized and fully structurally characterized including single-crystal X-ray diffraction analysis. 1-3 are organically templated hybrid layered materials comprising aquazinc(II) and aminium cations and sulfate anions. 1-3 are effective catalysts in the asymmetric Henry reaction; $\mathbf{1}$ being the most efficient one (yields up to $85 \%$ and threo/erythro diastereoselectivity up to 89:11).
\end{abstract}

Key words: Hybrid materials, Double salts, Crystal structures, Henry reaction, Diastereoselectivity 


\section{Introduction}

The organic-inorganic hybrid materials have recently attracted major interest in different fields of chemistry, partly due to their potential applications as dielectrics [1] or materials for nonlinear optics [2]. The organic-inorganic double salts are particular case of such materials, and synthesis of the lamellar mixed sulfates of transition metals and amines has been briefly described in the literature $[3,4]$. These double sulfates are usually composed from the stacked supramolecular sheets and can specifically activate some small organic molecules [5,6]. We believe that it is worthwhile to expand a number of the known inorganic-organic hybrid layered mixed salts and study their application as potential catalysts of the $\mathrm{C}-\mathrm{C}$ bond formation.

The nitroaldol (Henry) reaction is an important reaction for the formation of new $\mathrm{C}-\mathrm{C}$ bonds. It is widely used upon the synthesis of many organic compounds of e.g. pharmaceutical significance [7-11]. This reaction involves a combination of a nitroalkane and an aldehyde or ketone to form $\beta$-nitroalcohols (Scheme 1) and can be catalyzed by inorganic/organic bases or metal complexes [6-13]. A study of the catalytic activity of some double 2dihydromethylpiperazinediium-M(II) $\left(\mathrm{M}^{\mathrm{II}}=\mathrm{Cu}^{\mathrm{II}}, \mathrm{Fe}^{\mathrm{II}}, \mathrm{Co}^{\mathrm{II}}, \mathrm{Zn}^{\mathrm{II}}\right)$ sulfates upon the nitroaldol reaction has been recently published [6], and we believe that this line of investigation is worthwhile to be continued.

Scheme 1. Formation of nitroaldols by the Henry reaction.

Thus, in this work we focus on the preparation and characterization of three new inorganicorganic hybrid compounds $\mathbf{1 - 3}$ (Scheme 2) by combination of aromatic/heterocyclic amines, namely 
1-phenylethanamine, $1 \mathrm{H}$-benzo[d]imidazole and 2-methyl-1H-imidazole, with zinc(II) sulfate. The study of the catalytic activity of $\mathbf{1 - 3}$ is performed on the second part of this work.

Scheme 2. Schematic representations of 1-3.

\section{Experimental section}

\subsection{Materials}

$\mathrm{ZnSO}_{4} \cdot 7 \mathrm{H}_{2} \mathrm{O}$ (CARLO, ERBA), 1-phenylethanamine $\left(\mathrm{C}_{8} \mathrm{H}_{11} \mathrm{~N}\right)$ (Sigma Aldrich), 1Hbenzo[d]imidazole $\left(\mathrm{C}_{7} \mathrm{H}_{7} \mathrm{~N}_{2}\right)$ (Sigma Aldrich) and 2-methyl-1H-imidazole $\left(\mathrm{C}_{4} \mathrm{H}_{7} \mathrm{~N}_{2}\right)$ (Sigma Aldrich), $\mathrm{H}_{2} \mathrm{SO}_{4}$ (97\%, Aldrich) were received from commercial sources and used as received.

2.2. Synthesis

The compounds $\left(\mathrm{C}_{8} \mathrm{H}_{12} \mathrm{~N}\right)_{2}\left[\mathrm{Zn}\left(\mathrm{H}_{2} \mathrm{O}\right)_{4}\left(\mathrm{SO}_{4}\right)_{2}\right] \cdot 2 \mathrm{H}_{2} \mathrm{O}(\mathbf{1}),\left(\mathrm{C}_{7} \mathrm{H}_{7} \mathrm{~N}_{2}\right)_{2}\left[\mathrm{Zn}\left(\mathrm{H}_{2} \mathrm{O}\right)_{6}\right]\left(\mathrm{SO}_{4}\right)_{2} \cdot 4 \mathrm{H}_{2} \mathrm{O}$ (2) and $\left(\mathrm{C}_{4} \mathrm{H}_{7} \mathrm{~N}_{2}\right)_{2}\left[\mathrm{Zn}\left(\mathrm{H}_{2} \mathrm{O}\right)_{6}\right]\left(\mathrm{SO}_{4}\right)_{2} \cdot 2 \mathrm{H}_{2} \mathrm{O}$ (3) were obtained by slow evaporation, at room temperature, of zinc sulfate heptahydrate $\mathrm{ZnSO}_{4} \cdot 7 \mathrm{H}_{2} \mathrm{O}$ and corresponding amine, 1phenylethanamine (for 1), 1H-benzo[d]imidazole (for 2) or 2-methyl-1H-imidazole (for 3). The 
starting materials were dissolved in $10 \mathrm{ml}$ of distilled water with adjusted by addition of sulfuric acid $\mathrm{pH}<3$ and with the metal/amine molar ratio of $1: 2$. The solutions were stirred for $15 \mathrm{~min}$ and allowed to stand at room temperature. Single crystals having the form of sticks appeared after a few days. Then the products were filtered off and washed with a small amount of distilled water.

\subsection{Single-crystal diffraction data collection and structure determination}

Small crystals of the three compounds were glued to a glass fiber mounted on a four-circle Nonius Kappa CCD area-detector diffractometer (Centre de Diffractométrie X, UMR CNRS 6226). Intensity data sets were collected using MoK $\alpha$ radiation through the program COLLECT [14]. Correction for Lorentz-polarisation effect, peak integration and background determination were carried out with the program DENZO [15]. Frame scaling and unit cell parameters refinement were performed with the program SCALEPACK [15]. Analytical absorption corrections were performed by modelling the crystal faces [16]. The main crystallographic data are listed in Table 1.

Table 1. Crystallographic data.

\begin{tabular}{|c|c|c|c|}
\hline Empirical formula & $\mathrm{C}_{16} \mathrm{H}_{36} \mathrm{~N}_{2} \mathrm{ZnO}_{14} \mathrm{~S}_{2}(1)$ & $\mathrm{C}_{14} \mathrm{H}_{34} \mathrm{~N}_{4} \mathrm{ZnO}_{18} \mathrm{~S}_{2}(2)$ & $\mathrm{C}_{8} \mathrm{H}_{30} \mathrm{~N}_{4} \mathrm{ZnO}_{16} \mathrm{~S}_{2}(3)$ \\
\hline Formula & $\left(\mathrm{C}_{8} \mathrm{H}_{12} \mathrm{~N}\right)_{2}\left[\mathrm{Zn}\left(\mathrm{H}_{2} \mathrm{O}\right)_{4}\left(\mathrm{SO}_{4}\right)_{2}\right] \cdot 2 \mathrm{H}_{2} \mathrm{O}$ & $\left(\mathrm{C}_{7} \mathrm{H}_{7} \mathrm{~N}_{2}\right)_{2}\left[\mathrm{Zn}\left(\mathrm{H}_{2} \mathrm{O}\right)_{6}\right]\left(\mathrm{SO}_{4}\right)_{2} \cdot 4 \mathrm{H}_{2} \mathrm{O}$ & $\left(\mathrm{C}_{4} \mathrm{H}_{7} \mathrm{~N}_{2}\right)_{2}\left[\mathrm{Zn}\left(\mathrm{H}_{2} \mathrm{O}\right)_{6}\right]\left(\mathrm{SO}_{4}\right)_{2} \cdot 2 \mathrm{H}_{2} \mathrm{O}$ \\
\hline Formula weight & 609.96 & 675.94 & 567.85 \\
\hline Temperature (K) & 150 & 293 & 293 \\
\hline Crystal system & monoclinic & triclinic & monoclinic \\
\hline Space group & $P 2_{1} / n$ & $P-1$ & $P 2_{1} / c$ \\
\hline $\mathrm{a}(\AA)$ & $6.1831(3)$ & $6.7332(1)$ & $7.5665(2)$ \\
\hline$b(\AA)$ & $32.414(2)$ & $8.2398(2)$ & $23.3476(7)$ \\
\hline$c(\AA)$ & $7.0119(4)$ & $12.3305(2)$ & $6.6687(2)$ \\
\hline$\alpha(\operatorname{deg})$ & 90 & $84.575(1)$ & 90 \\
\hline$B(\operatorname{deg})$ & $108.525(2)$ & $79.877(1)$ & $109.426(2)$ \\
\hline$\gamma(\operatorname{deg})$ & 90 & $85.320(1)$ & 90 \\
\hline $\mathrm{V}\left(\AA^{3}\right)$ & $1332.51(14)$ & $668.96(2)$ & $1111.02(6)$ \\
\hline $\mathrm{Z}$ & 2 & 1 & 2 \\
\hline$\rho_{\text {cal }}\left(\mathrm{g} \cdot \mathrm{cm}^{-1}\right)$ & 1.520 & 1.678 & 1.697 \\
\hline Habit-colour & colorless & colorless & colorless \\
\hline$\lambda(\mathrm{MoK} \alpha)(\AA)$ & 0.71073 & 0.71073 & 0.71073 \\
\hline
\end{tabular}




\begin{tabular}{llll}
\hline$\mu\left(\mathrm{mm}^{-1}\right)$ & 1.14 & 1.16 & 1.37 \\
Unique data & 2998 & 9283 & 2546 \\
Observed data $[\mathrm{I}>2 \sigma(\mathrm{I})]$ & 2673 & 6848 & 2115 \\
$\mathrm{~F}(000)$ & 640 & 352 & 592 \\
$\mathrm{R}_{1}$ & 0.040 & 0.045 & 0.054 \\
$\mathrm{wR}_{2}$ & 0.098 & 0.141 & 0.156 \\
$\mathrm{GoF}$ & 1.08 & 1.01 & 1.08 \\
\hline
\end{tabular}

The structure analyses were carried out with the monoclinic symmetry, space groups $P 2_{1} / n$ and $P 2_{1} / c$, and the triclinic symmetry, space group $P \overline{\mathbf{1}}$, for $\mathbf{1}, \mathbf{3}$ and $\mathbf{2}$, respectively, according to the automated search for space group available in Wingx [17]. The zinc and sulfur atoms were located using the direct methods with program SHELXS-97 [18]. The organic moieties were determinated from successive Fourier calculations using SHELXL-97 [18]. The aqua H atoms were located in a difference map and refined with $\mathrm{O}-\mathrm{H}$ distance restraints of $0.85(2) \AA$ and $\mathrm{H} \cdots \mathrm{H}$ restraints of $1.39(2)$ $\AA$ so that the $\mathrm{H}-\mathrm{O}-\mathrm{H}$ angle fitted to the ideal value of a tetrahedral angle. $\mathrm{H}$ atoms bonded to $\mathrm{C}$ and $\mathrm{N}$ atoms were positioned geometrically and allowed to ride on their parent atoms, with $\mathrm{C}-\mathrm{H}=0.97$ $\AA$ and $\mathrm{N}-\mathrm{H}=0.90 \AA$.

\subsection{General procedure for the catalytic activity studies}

A mixture of catalyst (typically $3 \mathrm{~mol} \%)$, solvent $(2 \mathrm{~mL})$, aldehyde $(1 \mathrm{mmol})$ and nitroethane $(4 \mathrm{mmol})$ was stirred for the appropriate amount of time at room temperature, after which the solvent was evacuated. The residue was dissolved in DMSO- $d_{6}$ and analyzed by ${ }^{1} \mathrm{H}$ NMR $[6,12,13]$. The adequacy of this procedure was verified by blank ${ }^{1} \mathrm{H}$ NMR analyses with $1,2-$ dimethoxyethane as an internal reference.

\section{Results and discussion}

In this work three new compounds $\left(\mathrm{C}_{8} \mathrm{H}_{12} \mathrm{~N}\right)_{2}\left[\mathrm{Zn}\left(\mathrm{H}_{2} \mathrm{O}\right)_{4}\left(\mathrm{SO}_{4}\right)_{2}\right] \cdot 2 \mathrm{H}_{2} \mathrm{O} \quad$ (1), $\left(\mathrm{C}_{7} \mathrm{H}_{7} \mathrm{~N}_{2}\right)_{2}\left[\mathrm{Zn}\left(\mathrm{H}_{2} \mathrm{O}\right)_{6}\right]\left(\mathrm{SO}_{4}\right)_{2} \cdot 4 \mathrm{H}_{2} \mathrm{O}$ (2) and $\left(\mathrm{C}_{4} \mathrm{H}_{7} \mathrm{~N}_{2}\right)_{2}\left[\mathrm{Zn}\left(\mathrm{H}_{2} \mathrm{O}\right)_{6}\right]\left(\mathrm{SO}_{4}\right)_{2} \cdot 2 \mathrm{H}_{2} \mathrm{O} \quad$ (3) have been prepared by slow evaporation of the water solution of zinc(II) sulfate and 1-phenylethanamine, $1 \mathrm{H}-$ benzo[d]imidazole or 2-methyl-1H-imidazole. The supramolecular structures of the thus 
synthesized compounds are of the typical clay minerals (e.g. modified montmorillonite) [19] and some hybrid layered materials (e.g. phosphonates) [20], known for their intercalation and catalytic properties.

\subsection{Description of X-ray crystal structures of compounds 1-3}

The title compounds $\left(\mathrm{C}_{8} \mathrm{H}_{12} \mathrm{~N}\right)_{2}\left[\mathrm{Zn}\left(\mathrm{H}_{2} \mathrm{O}\right)_{4}\left(\mathrm{SO}_{4}\right)_{2}\right] \cdot 2 \mathrm{H}_{2} \mathrm{O} \quad(\mathbf{1}), \quad$ and $\left(\mathrm{C}_{4} \mathrm{H}_{7} \mathrm{~N}_{2}\right)_{2}\left[\mathrm{Zn}\left(\mathrm{H}_{2} \mathrm{O}\right)_{6}\right]\left(\mathrm{SO}_{4}\right)_{2} \cdot 2 \mathrm{H}_{2} \mathrm{O}(3)$ (Fig.) crystallize in the monoclinic system, space group $P 2_{1} / n$ and $P 2_{1} / c$, respectively, while $\left(\mathrm{C}_{7} \mathrm{H}_{7} \mathrm{~N}_{2}\right)_{2}\left[\mathrm{Zn}\left(\mathrm{H}_{2} \mathrm{O}\right)_{6}\right]\left(\mathrm{SO}_{4}\right)_{2} \cdot 4 \mathrm{H}_{2} \mathrm{O}$ (2) crystallizes in the triclinic system, space group $P \overline{1}$. Within the three structure types, the zinc atoms are located in special position on an inversion centre (Wyckoff site: 2a; 1 e and 2b in 1, 2 and $\mathbf{3}$, respectively) while all the other atoms occupy general positions. In the structure of $\mathbf{1}$ the divalent metal cation is octahedrally coordinated by one oxygen atom belonging to a sulfate group, two water molecules and their corresponding centrosymmetrically located atoms. Each metallic octahedron shares two oxygen atoms with two sulfate groups to form the $\left[\mathrm{Zn}\left(\mathrm{SO}_{4}\right)_{2}\left(\mathrm{H}_{2} \mathrm{O}\right)_{4}\right]^{2-}$ units,. These later are stabilized and connected together through strong $\mathrm{OW}-\mathrm{H} \cdots \mathrm{O}$ hydrogen bonds. In the compounds $\mathbf{2}$ and $\mathbf{3}$, the zinc cation coordinates six water molecules to form the hexaaquacoordinated complex, $\left[\mathrm{Zn}\left(\mathrm{H}_{2} \mathrm{O}\right)_{6}\right]^{2+}$. Within the zinc metallic octahedron, the $\mathrm{Zn}-\mathrm{O}$ distances range between $2.065(2)$ and $2.114(2) \AA$ in 1, between $2.0456(10)$ and $2.1532(10) \AA$ in 2 and from $2.0844(27)$ to $2.1008(30) \AA$ in 3 . The octahedral environment around zinc atoms is quite regular in all three compounds and is similar with those described in the literature. The inorganic sheet consists of isolated metallic octahedra, sulfate tetrahedra and free water molecules linked together by $\mathrm{O}-\mathrm{H} \cdots \mathrm{O}$ hydrogen-bonding network. 


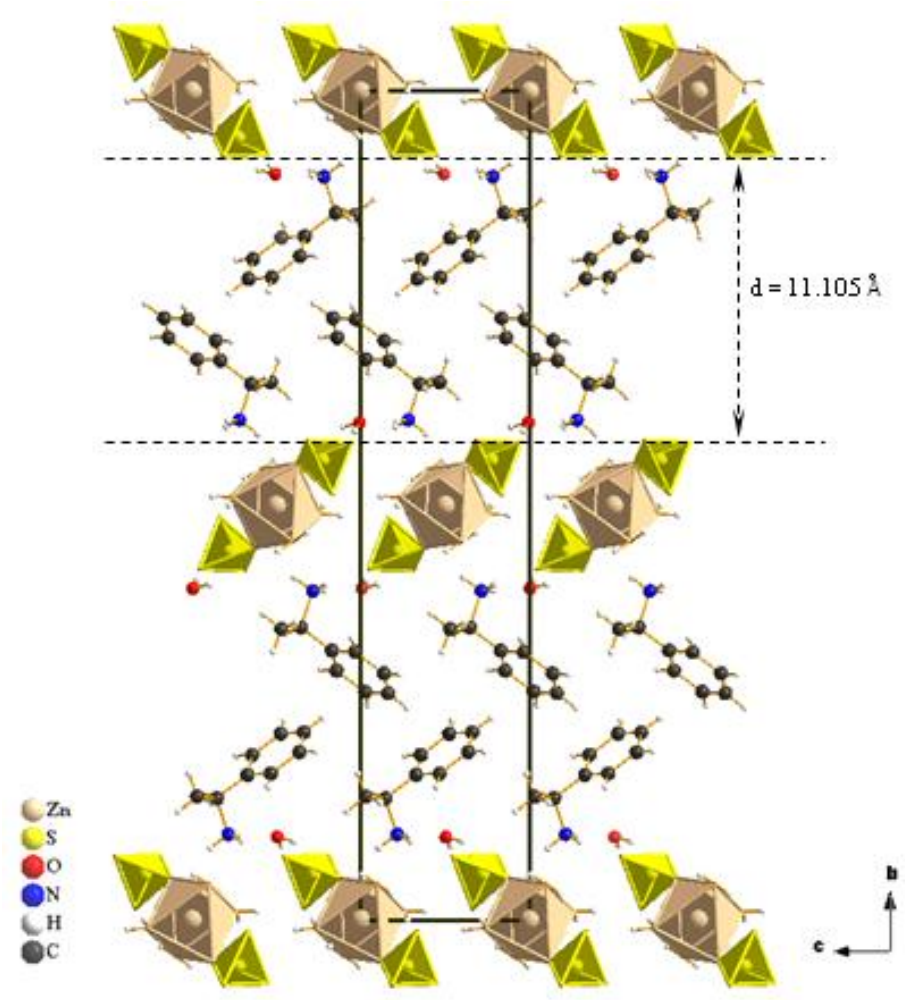

(a)

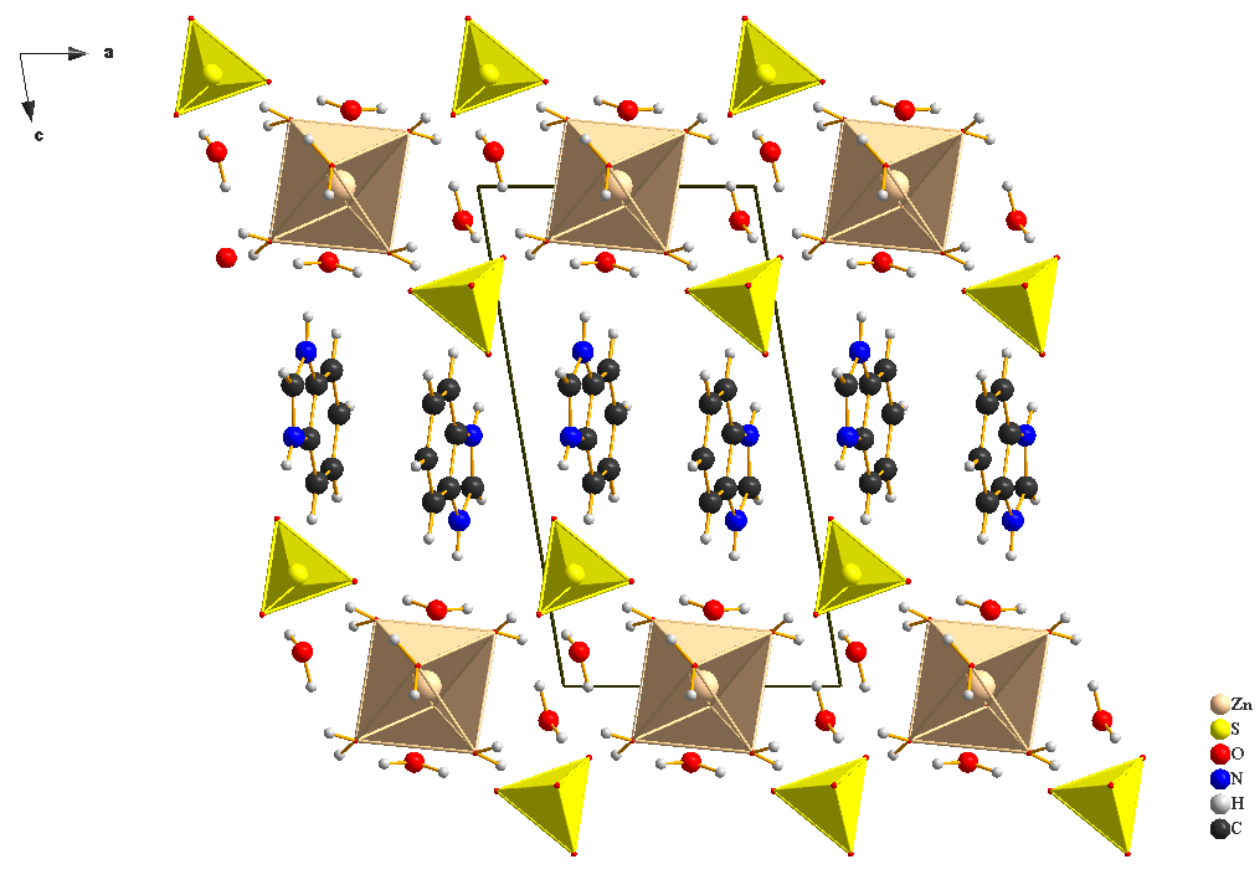

(b) 


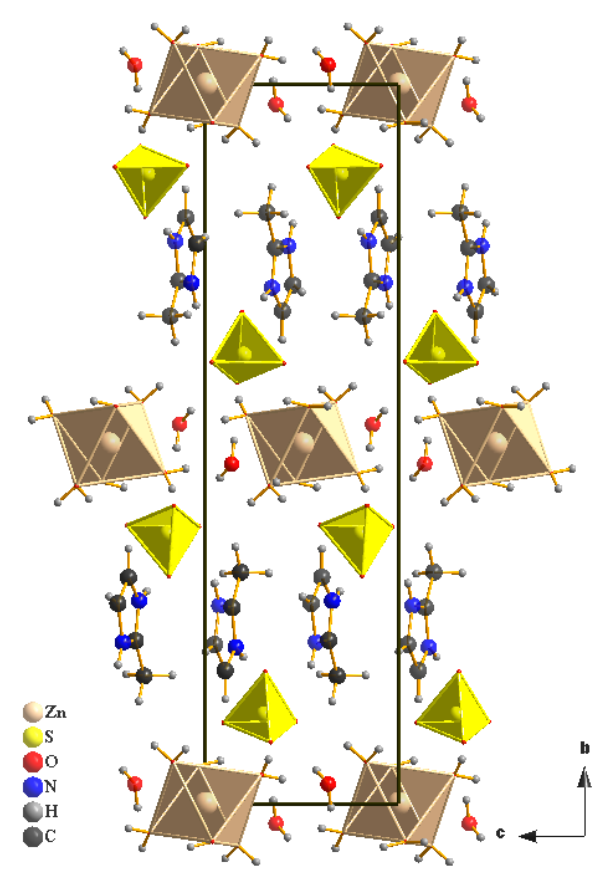

(c)

Fig. Projection of the crystal structure of 1, 2 and 3 along

the $a$-axis (a), $b$-axis (b) and $a$-axis (c), respectively.

The supramolecular crystal structures of 1-3 are built from the alternatively arranged inorganic and organic layers. For instance, 1 comprises an alternate stacking of inorganic layers, built of $\left[\mathrm{Zn}\left(\mathrm{SO}_{4}\right)_{2}\left(\mathrm{H}_{2} \mathrm{O}\right)_{4}\right]^{2-}$ anions, and organic layers of $\left(\mathrm{C}_{8} \mathrm{H}_{12} \mathrm{~N}\right)^{+}$cations along the crystallographic $b$-axis, while the free water molecules are intercalated between the organic and inorganic sheets [Fig. (a)]. The interlayer space between two inorganic layers in this compound is of 11.105 ̊. The compounds 2 and 3 [Fig. (b) and (c)] also present an alternate structural arrangement of inorganic layers, containing isolated $\left[\mathrm{Zn}\left(\mathrm{H}_{2} \mathrm{O}\right)_{6}\right]^{2+}$ cations, $\left(\mathrm{SO}_{4}\right)^{2-}$ anions and free $\mathrm{H}_{2} \mathrm{O}$ molecules, and organic layers, formed by the corresponding protonated amines along $c$ and $b$ crystallographic axis, respectively. In all the structures, the organic cations are interlayed within the inorganic framework to compensate the negative charge of the inorganic part. The overall structures are stabilized by $\mathrm{O}-\mathrm{H} \cdots \mathrm{O}$ hydrogen bonding between the different inorganic entities, $\mathrm{N}-\mathrm{H} \cdots \mathrm{O}$ hydrogen bonding between the inorganic and organic moieties and $\pi$ stacking interactions between 
the aromatic rings of the amine molecules themselves. In compound $\mathbf{1}, \mathrm{O}-\mathrm{H} \cdots \mathrm{O}$ distances are between $2.714(2)$ and $2.896 \AA$ and $\mathrm{N}-\mathrm{H} \cdots \mathrm{O}$ distances are between 2.741(3) and 2.851(3) $\AA$. Intermolecular $\mathrm{O}-\mathrm{H} \cdots \mathrm{O}$ bonds in compound 2 are ranging between $2.6967(16)$ and 2.8674(16) $\AA$, while $\mathrm{N}-\mathrm{H} \cdots \mathrm{O}$ bonds are equal to $2.7135(16)$ and $2.9356(18) \AA$. In the last third compound O$\mathrm{H} \cdots \mathrm{O}$ bonds are ranging from 2.689(4) $\AA$ to 2.888(4) $\AA$ and $\mathrm{N}-\mathrm{H} \cdots \mathrm{O}$ bonds are equal to 2.702(4) and 2.858(4) ̊.

In the three structures, the organic sheet is formed by the protonated amines which are linked together through the aromatic-aromatic interactions. A perpendicular arrangement of the benzene rings to form a T-shaped configuration [21] occurs in $\mathbf{1}$. The angle between two T-shaped aromatic rings is $84.037(88)^{\circ}$ and the centroid-centroid distance is of 5.0096(2) $\AA$ which allows to enable a $\mathrm{C}-\mathrm{H} \cdots \pi$ interaction with a distance of $2.9432(1) \AA$. . the $\pi \cdots \pi$ interactions in 3 and 2 are of the parallel-displaced configurations $[21,22]$ with a vertical distance 3.4110(1) $\AA$ and 3.5275(0) $\AA$ between two stacked rings, respectively. Each organic cation engages its hydrogen atoms bonded to $\mathrm{N}$ atoms in $\mathrm{N}-\mathrm{H} \cdots \mathrm{O}$ hydrogen bonds and participates in the structure cohesion through intermolecular H-bonds established between the organic and inorganic layers. The water molecules also play an important role in the cohesion of the structure as a ligand and as a participant of the hydrogen bonds linking different cationic and anionic entities. Generally, the structural arrangement and the distances of interlayer spacing depend on size and shape of the amino groups involved in the structure formation.

\subsection{Catalytic activity of $\mathbf{1}-\mathbf{3}$ in the Henry reaction}

Initially the effect of solvents has been studied to optimize the reaction conditions. For this purpose we have chosen benzaldehyde and nitroethane as model reactants and performed the reaction at room temperature with such solvents as protic methanol, water and aprotic $\mathrm{MeCN}$. As can be seen from Table 2 (entries 1-9), the application of $\mathrm{MeOH}$ and $\mathrm{MeCN}$, in spite of their 
similar polarity, leads to different conversions of $77 \%$ for $\mathrm{MeOH}$ and $28 \%$ for $\mathrm{MeCN}$. Most probably this difference is due to the protic character of $\mathrm{MeOH}$ which supports the proton shift in intermediates upon catalytic cycle as reported in [12]. Additionally, good solubility of the starting materials and reaction products in $\mathrm{MeOH}$ can positively affect the process. However, the reaction in $\mathrm{H}_{2} \mathrm{O}$ gave lower yields in comparison to $\mathrm{MeOH}$, and in general the conversion changes in the order $\mathrm{MeOH}>\mathrm{H}_{2} \mathrm{O}>\mathrm{MeCN}$ for the studied solvents. Therefore, the subsequent reactions presented in Table 2 (entries 4-6 and 10-20) and Table 3 is performed in $\mathrm{MeOH}$. At comparable conditions, $\mathbf{1}$ appears to be most active catalyst among the three $\left(\mathrm{H}_{2} \mathrm{O}, \mathrm{MeOH}, \mathrm{MeCN}\right)$ for other studies, Table 3 .

Table 2. Henry nitroaldol reaction between benzaldehyde and nitroethane with $\mathbf{1}-\mathbf{3}$ as catalyst precursors. $^{\text {a }}$

\begin{tabular}{|c|c|c|c|c|c|c|c|}
\hline Entry & Catalyst & Time, (h) & $\begin{array}{c}\text { Amount of } \\
\text { catalyst (mol\%) }\end{array}$ & $\begin{array}{l}\text { Temp. } \\
\left({ }^{\circ} \mathrm{C}\right)\end{array}$ & Solvent & $\begin{array}{l}\text { Yield, } \\
(\%)^{\mathrm{b}}\end{array}$ & $\begin{array}{l}\text { Selectivity }^{\mathrm{c}} \\
\text { threo/ erythro }\end{array}$ \\
\hline 1 & 1 & 24 & 2.0 & 20 & $\mathrm{H}_{2} \mathrm{O}$ & 43.3 & $76: 24$ \\
\hline 2 & 2 & 24 & 2.0 & 20 & $\mathrm{H}_{2} \mathrm{O}$ & 27.5 & $62: 38$ \\
\hline 3 & 3 & 24 & 2.0 & 20 & $\mathrm{H}_{2} \mathrm{O}$ & 30.7 & $67: 33$ \\
\hline 4 & 1 & 24 & 2.0 & 20 & $\mathrm{MeOH}$ & 77.3 & $86: 14$ \\
\hline 5 & 2 & 24 & 2.0 & 20 & $\mathrm{MeOH}$ & 35.2 & $65: 35$ \\
\hline 6 & 3 & 24 & 2.0 & 20 & $\mathrm{MeOH}$ & 41.6 & $69: 31$ \\
\hline 7 & 1 & 24 & 2.0 & 20 & $\mathrm{MeCN}$ & 28.5 & $70: 30$ \\
\hline 8 & 2 & 24 & 2.0 & 20 & $\mathrm{MeCN}$ & 18.3 & $58: 42$ \\
\hline 9 & 3 & 24 & 2.0 & 20 & $\mathrm{MeCN}$ & 24.9 & $63: 37$ \\
\hline 10 & Blank & 24 & - & 20 & $\mathrm{MeOH}$ & - & - \\
\hline 11 & $\mathrm{ZnCl}_{2}$ & 24 & 3.0 & 20 & $\mathrm{MeOH}$ & - & - \\
\hline 12 & 1 & 24 & 1.0 & 20 & $\mathrm{MeOH}$ & 70.8 & $86: 14$ \\
\hline
\end{tabular}




\begin{tabular}{|l|c|c|c|c|c|c|c|}
\hline 13 & 1 & 24 & 3.0 & 20 & $\mathrm{MeOH}$ & 83.5 & $87: 13$ \\
\hline 14 & $\mathbf{1}$ & 24 & 4.0 & 20 & $\mathrm{MeOH}$ & 83.7 & $87: 13$ \\
\hline 15 & $\mathbf{1}$ & 5 & 3.0 & 20 & $\mathrm{MeOH}$ & 55.6 & $86: 14$ \\
\hline 16 & $\mathbf{1}$ & 10 & 3.0 & 20 & $\mathrm{MeOH}$ & 74.2 & $86: 14$ \\
\hline 17 & $\mathbf{1}$ & 15 & 3.0 & 20 & $\mathrm{MeOH}$ & 79.9 & $87: 13$ \\
\hline 18 & $\mathbf{1}$ & 48 & 3.0 & 20 & $\mathrm{MeOH}$ & 84.2 & $87: 13$ \\
\hline & $\mathbf{1}$ & 15 & 3.0 & 35 & $\mathrm{MeOH}$ & 84.2 & $87: 13$ \\
\hline 19 & 1 & 15 & 3.0 & 45 & $\mathrm{MeOH}$ & 87.1 & $88: 12$ \\
\hline
\end{tabular}

${ }^{a}$ Reaction conditions: $1.0-4.0 \mathrm{~mol} \%(0.1-0.4 \mu \mathrm{mol})$ of catalyst precursor (typically $\left.3 \mathrm{~mol} \%\right)$, solvent $\left(\mathrm{H}_{2} \mathrm{O}, \mathrm{MeOH}\right.$, $\mathrm{MeCN})(2 \mathrm{~mL})$, nitroethane $(4 \mathrm{mmol})$ and benzaldehyde $(1 \mathrm{mmol}){ }^{\mathrm{b}}$ Determined by ${ }^{1} \mathrm{H} \mathrm{NMR}$ analysis (see Experimental). ${ }^{\mathrm{c}}$ Calculated by ${ }^{1} \mathrm{H} \mathrm{NMR}$.

The product of $\mathrm{C}-\mathrm{C}$ coupling was not detected in the blank experiments in the absence of 1-3 (Table 2, entries 10,11), hence, these compounds are essential for performance of this reaction. Generally, the conversion increases with rise of the catalyst amount although the diasteroselectivity is not significantly influenced (Table 2, entries 4, 12-14). The catalyst content of 3 mol\% appears to be appropriate and thus was chosen for further studies. The reaction time has significant effect on the yield of nitroaldol products, however, the yield does not change much after $24 \mathrm{~h}$ (Table 2, entries 13, 15-18). The temperature does not strongly affect the reaction (entries 13,19 and 20), thus, generally studies were performed at room temperature.

The application of different aromatic and aliphatic aldehydes as starting materials allowed to conclude that the use of substrates with electron withdrawing groups generally gives higher yields (Table 3, entry 2). Interestingly, the nitroaldol product was also obtained with good yield and diasteroselectivity even when sterically hindered ortho-methylbenzaldehyde was employed as an electrophile (entry 4). Aliphatic aldehydes also were found to be good substrates under the studied 
reaction conditions, providing the corresponding products in high yields and diasteroselectivities (entries 5,6).

Table 3. Henry reaction of various aldehydes and nitroethane with catalyst $\mathbf{1}^{\text {a }}$

\begin{tabular}{|c|c|c|c|}
\hline Entry & Substrate & Yield $(\%)^{b}$ & threo/erythro ratio $^{c}$ \\
\hline 1 & & 83.5 & $87: 13$ \\
\hline 2 & & 85.1 & $89: 11$ \\
\hline 3 & & 80.2 & $82: 18$ \\
\hline 4 & & 77.6 & $78: 22$ \\
\hline 5 & $\mathrm{CH}_{3} \mathrm{CHO}$ & 92.1 & $90: 10$ \\
\hline 6 & $\mathrm{CH}_{3} \mathrm{CH}_{2} \mathrm{CHO}$ & 88.3 & $89: 11$ \\
\hline
\end{tabular}

${ }^{\text {a }}$ Reaction conditions: $3.0 \mathrm{~mol} \%$ of catalyst 1, MeOH $(2 \mathrm{~mL})$, nitroethane $(4 \mathrm{mmol})$ and benzaldehyde $(1 \mathrm{mmol})$, reaction time: $15 \mathrm{~h} .{ }^{\mathrm{b}}$ Determined by ${ }^{1} \mathrm{H}$ NMR analysis (see Experimental). ${ }^{\mathrm{c}}$ Calculated by ${ }^{1} \mathrm{H}$ NMR.

\section{Conclusions}

Three new organic-inorganic mixed materials 1-3 were synthesized and fully structurally characterized. All the three compounds possess the layered supramolecular structures with alternate arrangement of inorganic layers, containing zinc(II)-aqua cations, sulfate anions and free $\mathrm{H}_{2} \mathrm{O}$ 
molecules, and organic layers, formed by aminium ions. 1-3 were proven to be efficient and diasteroselective catalysts for the nitroaldol (Henry) reaction.

\section{Acknowledgements}

This work has been partially supported by the Foundation for Science and Technology (FCT) (projects PTDC/QUI-QUI/102150/2008 and PEst-OE/QUI/UI0100/2011) and by TunisoPortuguese Scientific and Technical Cooperation 2009 Program.

\section{Appendix A. Supplementary material}

CCDC 923144, 923143 and 923145 contain the supplementary crystallographic data for complexes 1, 2 and $\mathbf{3}$ respectively. These data can be obtained free of charge via http://www.ccdc.cam.ac.uk/conts/retrieving.html, or from the Cambridge Crystallographic Data Centre, 12 Union Road, Cambridge CB2 1EZ, UK; fax: (+44) 1223-336-033; or e-mail: deposit@ccdc.cam.ac.uk. Supplementary data associated with this article can be found, in the online version, at http://dx.doi.org/..

\section{References}

[1] L.F. Kirpichnikova, L.A. Shuvalov, N.R. Ivanov, Ferroelectrics 96 (1989) 313.

[2] R. Masse, J. Zyss, European Patent EP 0488869 B1 (1996).

[3] J. Lee, O.K. Farha, J. Roberts, K.A. Scheidt, S.T. Nguyen, J.T. Hupp, Chem. Soc. Rev. 38 (2009) 1450.

[4] G. Centi, S. Perathoner, Micropor. Mesopor. Mater. 1-2 (2008) 3.

[5] C. Cascales, B.G. Lor, E.G. Puebla, M. Iglesias, M.A. Monge, C.R. Valero, N. Snejko Chem. Mater. 16 (2004) 4144. 
[6] H. Naïli, F. Hajlaoui, T. Mhiri, T.C.O. Mac Leod, M.N. Kopylovich, K.T. Mahmudov, A.J.L. Pombeiro, Dalton Trans. 42 (2013) 399.

[7] A. Dhakshinamoorthy, M. Opanasenko, J. Cejka, H. Garcia, Adv. Synth. Catal. 355 (2013) 247.

[8] A.G. Doyle, E.N. Jacobsen, Chem. Rev. 107 (2007) 5713.

[9] F.A. Luzzio, Tetrahedron 57 (2001) 915.

[10] F. López, A.J. Minnaard, B.L. Feringa, Acc. Chem. Res. 40 (2007) 179.

[11] A.H. Hoveyda, A.W. Hird, M.A. Kacprzynski, Chem. Commun. (2004) 1779.

[12] M.N. Kopylovich, T.C.O. Mac Leod, K.T. Mahmudov, M.F.C. Guedes da Silva, A.J.L. Pombeiro, Dalton Trans. 40 (2011) 5352.

[13] M.N. Kopylovich, A. Mizar, M.F.C. Guedes da Silva, T.C.O. Mac Leod, K.T. Mahmudov, A.J.L. Pombeiro, Chem. A Eur. J. 19 (2013) 588.

[14] Nonius, Kappa CCD Program Software, Nonius BV, Delft, The Netherlands, 1998.

[15] Z. Otwinowski, W. Minor, in: C.W. Cater, R.M. Sweet (Eds.), Methods in Enzymology, Vol. 276, Academic Press, New York, 1997, p. 307.

[16] P. Coppens, in: F.R. Ahmed, S.R. Hall, C.P. Huber (Eds.), Crystallographic Computing, Munksgaard Publishers, Copenhagen (1970) 255.

[17] L.J. Farrugia, J. Appl. Crystallogr. 32 (1999) 837.

[18] G.M. Sheldrick, SHELXL-97, Programs for Crystal Structure Refinement, University of Göttingen, Germany (1997).

[19] Y. Zidane, A. Ourari, T. Bataille, P. Hapiot, D. Hauchard, J. Electroanal. Chem. 641 (2010) 64.

[20] G. Alberti, M. Casciola, U. Costantino, R. Vivani, Adv. Mater. 8 (1996) 291.

[21] M.O. Sinnokrot, E.F. Valeev, C.D. Sherrill, J. Am. Chem. Soc. 124 (2002) 10887.

[22] N.J. Singh, S.K. Min, D.Y. Kim, K.S. Kim, J. Chem. Theory Comput. 5 (2009) 515. 